\title{
A linkage map of 10 loci flanking the Marfan syndrome locus on 15q: results of an International Consortium Study
}

This paper is dedicated to the memory of Dr David Hollister, a physician, scientist, and friend, whose seminal contributions in connective tissue research, and Marfan syndrome in particular have shaped the field.

Molecular Genetics Laboratory,

Department of

Pediatrics, University of Connecticut Health Center, 263

Farmington Avenue,

Farmington, CT

06030, USA.

M Sarfarazi

P Tsipouras

Department of Clinical Genetics,

Birmingham

University,

Birmingham.

R Del Mastro

M Kilpatrick

Clinical Genetics

Unit, Birmingham

Maternity Hospital,

Birmingham.

P Farndon

Human Genetics

Section, Departments

of Pathology and

Medicine, Ninewells

Hospital and Medical

School, Dundee.

M Boxer

A Bridges

\section{Génétique et}

Pathologie Foetale,

INSERM, Unite 73,

Chateau de

Longchamp, 75016

Paris, France.

C Boileau

C Junien

Human Genetics Unit, University of

Edinburgh,

Edinburgh,

C Hayward

D Brock

\section{Department of} Cardiological

Sciences, St George's

Hospital Medical

School, London.

A Child

Correspondence to Dr Sarfarazi.

Received 10 July 1991.

Revised version accepted

7 August 1991.

Mansoor Sarfarazi, Petros Tsipouras, Richard Del Mastro, Michael Kilpatrick, Peter Farndon, Maureen Boxer, Alan Bridges, Catherine Boileau, Claudine Junien, Caroline Hayward, David Brock, Anne Child

\begin{abstract}
Members of an International Consortium for Linkage Analysis of the Marfan Syndrome (MFS1) have pooled data for joint analysis in an attempt to determine the precise location of the MFS1 gene and the order of 10 DNA markers on 15q. Five laboratories performed a total of 2111 genotypes in 22 families consisting of 225 affected and 248 normal subjects. For each marker a mean of 98 meioses was informative. $D 15 S 48$ and $D 15 S 1$ were identified as the closest linked markers with $99 \%$ upper confidence intervals of $12 \%$ and $13 \%$ respectively. We have used the CRI-MAP program to construct the most likely order as: D15S24-D15S25D15S1-MFS1-D15S48-D15S49-(D15S45) S51)-(D15S29/S38). Placement of D15S2 in relation to $-D 15 S 1-D 15 S 48$ - cannot be determined with certainty. The genetic map of these markers extends $53.6 \mathrm{cM}$ in males and $65.0 \mathrm{cM}$ in females with a sex averaged map of $60.7 \mathrm{cM}$. The sex difference was statistically significant $(p=0.005)$. Linkage heterogeneity between 22 MFS1 families was documented $(p=0.009)$ necessitating the exclusion of one family from the analysis. However, comparison of the remaining 21 families for two point and multipoint lod scores showed no evidence for linkage heterogeneity of the MFS1 locus.
\end{abstract}

Marfan syndrome (MFS1) is an autosomal dominant connective tissue disorder with an estimated prevalence of about 4 to 6 per 100000 persons. ${ }^{1}$ The diagnosis of Marfan syndrome is entirely dependent on internationally agreed clinical criteria. ${ }^{2}$ The lack of a specific genetic or biochemical test compounded by the presence of significant variability of clinical expression between subjects and families gave impetus to an active search for the localisation, identification, and characterisation of the MFS1 gene. In response to this need, an International Consortium for MFS1 linkage was organised to expedite this process by sharing DNA probes, exchanging information on research techniques, and by pooling data. From the combined results of genetic linkage presented at the first meeting of the Consortium ${ }^{3}$ or subsequently sent to one of us (MS), an initial exclusion map of this condition was constructed. ${ }^{4}$ Other exclusion maps for the MFS1 locus were produced periodically. The last map constructed in May 1990 was based on more than 140 markers.

Shortly after this the MFS1 locus was assigned to chromosome 15 by positional mapping in five Finnish families ${ }^{5}$; confirmation of this location has followed in other families and with additional probes. ${ }^{6-8}$ Rapid progress has since been made in the fine mapping of this locus. In this paper we report the combined two point and multipoint linkage analyses of $M F S 1$ and 10 DNA markers on the 15q15q21 region from analysis of the pooled data from all participating groups. This has allowed an accurate ordering of the DNA markers, improved the estimates of genetic distances, and determined the exact location of the MFS1 locus, which was not necessarily discernible in each individual dataset. Five members of the MFS1 Consortium submitted their pedigrees and genotypic data for use in a combined genetic analysis.

\section{Methods}

THE FAMILY PANEL

The Consortium members contributed a total of 22 autosomal dominant MFS1 families for the joint analyses. All pedigrees and their genotypic data were transferred into the DBLINK database ${ }^{9}$ and subsequently plotted using the dedicated pedigree drawing program PLOT2000. ${ }^{10}$ Pedigrees were then screened for incompatibilities, structural, genotypic, coding, and typing errors both manually and by an initial screening of recombinants. Any discrepancies were resolved through discussion with the contributing investigator and by resampling and retyping those subjects concerned. The composite clinical phenotype of each family studied was consistent with the diagnosis of MFS1 according to diagnostic criteria previously established and widely accepted. $^{2}$ 
Table 1 DNA markers used in this study.

\begin{tabular}{|c|c|c|c|c|c|c|}
\hline Locus & Probe & Enzyme & $\begin{array}{c}\text { Allele } \\
\text { frequency* }\end{array}$ & $\mathrm{H}+$ & PIC $\ddagger$ & Reference \\
\hline $\begin{array}{l}D 15 S 24 \\
D 15 S 25 \\
D 15 S 2 \\
D 15 S 1 \\
D 15 S 48 \\
D 15 S 49 \\
D 15 S 51 \\
D 15 S 45 \\
D 15 S 29 \\
D 15 S 38\end{array}$ & $\begin{array}{l}\text { CMW1 } \\
\text { pTHH114 } \\
\text { pDP151 } \\
\text { pMS1-14 } \\
\text { CRI-L442 } \\
\text { CRI-L1204 } \\
\text { CRI-P452 } \\
\text { pEFZ33 } \\
\text { pEFD49.3 } \\
\text { pEFD49.2 }\end{array}$ & $\begin{array}{l}\text { EcoRI } \\
R s a \mathrm{I} \\
\text { EcoRI } \\
\text { MspI } \\
\text { MspI } \\
\text { MspI } \\
\text { MspI } \\
\text { HindIII } \\
\text { TaqI } \\
\text { TaqI }\end{array}$ & $\begin{array}{l}0 \cdot 19 \S \\
0 \cdot 41 \\
0 \cdot 29 \\
0 \cdot 39 \\
0 \cdot 16 \\
0 \cdot 38 \\
0 \cdot 26 \\
0 \cdot 29 \\
0 \cdot 28 \\
0 \cdot 29\end{array}$ & $\begin{array}{l}0.74 \\
0.49 \\
0.41 \\
0.48 \\
0.73 \\
0.47 \\
0.39 \\
0.41 \\
0.41 \\
0.49\end{array}$ & $\begin{array}{l}0 \cdot 69 \\
0 \cdot 37 \\
0 \cdot 33 \\
0 \cdot 36 \\
0 \cdot 69 \\
0 \cdot 36 \\
0 \cdot 31 \\
0 \cdot 33 \\
0.33 \\
0 \cdot 37\end{array}$ & 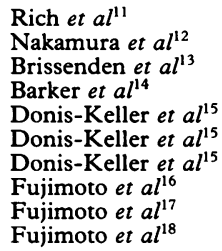 \\
\hline
\end{tabular}

* The least frequent allele. Allelic frequencies, $\mathrm{H}$, and PIC values are based on our sample. $\dagger \mathrm{H}=$ heterozygosity. $\ddagger \mathrm{PIC}=$ polymorphic information content. $§$ Multiallelic system. $\|$ Haplotyped frequency.

Table 2 Summary of the pedigrees and their genotypic data.

\begin{tabular}{lccc}
\hline Centre & $\begin{array}{c}\text { No of } \\
\text { families }\end{array}$ & $\begin{array}{c}\text { No of } \\
\text { affected/totals }\end{array}$ & $\begin{array}{c}\text { No of } \\
\text { genotypes }\end{array}$ \\
\hline Farmington & 13 & $123 / 241$ & 1273 \\
Birmingham & 5 & $41 / 75$ & 238 \\
Edinburgh & 2 & $19 / 35$ & 111 \\
Dundee & 1 & $14 / 33$ & 241 \\
Paris & 1 & $28 / 89$ & 248 \\
Totals & 22 & $225 / 473$ & 2111 \\
\hline
\end{tabular}

The 22 pedigrees combined a total of 478 subjects with an average number of 22 persons per pedigree ( 16 children and six sets of parents). The dataset included 225 affected and 248 unaffected subjects, as well as five of unknown clinical status whose genotypic data were useful in ordering the DNA markers, but were not used to determine the location of MFS1. The DNA markers used in this study are listed in table 1 . A total of 2111 genotypes was performed by the participating laboratories using 10 DNA markers (table 2).

\section{Linkage analysis}

A total of five laboratories has contributed genotypic data on 10 DNA markers. One of the markers, $D 15 S 48,,^{15}$ is polymorphic for more than one enzyme so the genotypic data of this marker have been haplotyped in all subsequent analyses. Table 3 summarises the genetic linkage data contributed by the Consortium members on the MFS1 locus and the DNA markers. There is a total of 317 informative meioses for the MFS1 locus of which 235 are potentially phase known. The largest number of subjects was genotyped for $D 15 S 1$ (170) and the smallest number for D15S51 and D15S38 (24 and 25 respectively), with an average of 98 meioses per marker.

Table 3 Summary of linkage data for the combined dataset.

\begin{tabular}{lcccc}
\hline & \multicolumn{4}{c}{ Total No of informative } \\
\cline { 2 - 5 } & Families & Phase known & Phase unknown & Meioses \\
\hline MFS1 & 22 & 235 & 82 & 317 \\
D15S24 & 8 & 7 & 61 & 68 \\
D15S25 & 12 & 5 & 76 & 81 \\
D15S2 & 15 & 4 & 94 & 98 \\
D15S1 & 18 & 9 & 161 & 170 \\
D15S48 & 17 & 6 & 91 & 155 \\
D15S49 & 10 & 0 & 24 & 97 \\
D15S51 & 5 & 3 & 96 & 24 \\
D15S29 & 10 & 8 & 104 & 112 \\
D15S38 & 8 & 0 & 25 & 25 \\
\hline
\end{tabular}

The two point univariate linkage analyses between the MFS1 locus and the DNA markers and between the markers themselves were carried out with the MLINK program of the LINKAGE package ${ }^{19}$ (v 5.03). The Marfan locus was defined as having full penetrance and a population frequency of 0.0001 . The sex specific and sex averaged analyses were carried out with CRI-MAP (v 2.4.2) program (P Green, personal communication). ${ }^{1520}$ The heterogeneity testing was carried out with both the HOMOG (v 3.0) and HOMOG2 (v 2.75) programs. ${ }^{21}$ The multipoint analysis was performed using the CRI-MAP program.

In order to construct a more accurate map, we first used the available genotypic data from version 4 of the CEPH database ${ }^{22}$ and built a framework map ${ }^{23}$ of all the markers in the region of the interest. Sex specific and sex averaged maps were then generated for this map. The estimated recombination fractions between the loci obtained by the multipoint linkage analysis were converted to centimorgans using the Kosambi mapping function.

\section{Results}

Initial examination of recombinants between the MFS1 locus and the marker loci identified one family (French pedigree) as being different from the remaining 21. Affected members of this family had typical skeletal and cardiovascular manifestation but none had ectopia lentis after careful slit lamp examination..$^{24}$ This family is only informative for D15S1, D15S48, D15S49, and D15S38. Multipoint linkage analysis of this family and the fixed order of D15S1-MFS1-D15S48D15S49-D15S38 produced a location score of -0.463 . For this order, three subjects (two normal males and one affected female) showed double crossovers with $M F S 1$ and the four DNA markers (out of a total of 14 recombinants). The highest location score $(1.482)$ for this family was obtained when MFS1 was placed distally to $D 15 S 38$. Under this assumption the three double crossovers can be explained by a single crossover event. Analysis of heterogeneity testing with the HOMOG program and for D15S1 showed that this family is significantly different from others $(p=0.009$, table 4$)$. Because of this observation we decided to exclude this family from further analysis. All the data presented in tables 5, 6, 7, and 8 exclude this family and are only based on the remaining 21 families. 
Table 4 Result of MFS1 heterogeneity testing with marker loci using the HOMOG program*.

\begin{tabular}{|c|c|c|c|c|c|c|c|c|}
\hline \multirow[b]{2}{*}{ Locus } & \multicolumn{4}{|c|}{ Including the French family } & \multicolumn{4}{|c|}{ Excluding the French family } \\
\hline & No & $\chi_{1}^{2}$ & $\mathbf{p}$ & $\mathbf{L}(\mathbf{R})$ & No & $\chi_{1}^{2}$ & $\mathbf{p}$ & $\mathbf{L}(\mathbf{R})$ \\
\hline $\begin{array}{l}D 15 S 24 \\
D 15 S 25 \\
D 15 S 1 \\
D 15 S 2 \\
D 15 S 48 \\
D 15 S 49 \\
D 15 S 51 \\
D 15 S 45 \\
D 15 S 29 \\
D 15 S 38\end{array}$ & $\begin{array}{r}8 \\
12 \\
18 \\
15 \\
17 \\
10 \\
5 \\
10 \\
8 \\
1\end{array}$ & $\begin{array}{c}0.00 \\
0.00 \\
5.44 \\
2.41 \\
0.00 \\
0.00 \\
0.00 \\
0.39 \\
0.00 \\
\text { Not done }\end{array}$ & $\begin{array}{l}0.500 \\
0.500 \\
0.009 \\
0.060 \\
0.500 \\
0.500 \\
0.500 \\
0.265 \\
0.500\end{array}$ & $\begin{array}{r}1.00 \\
1.00 \\
15 \cdot 16 \\
3.34 \\
1.00 \\
1.00 \\
1.00 \\
1.22 \\
1.00\end{array}$ & $\begin{array}{r}8 \\
12 \\
17 \\
15 \\
16 \\
9 \\
5 \\
10 \\
8 \\
0\end{array}$ & $\begin{array}{c}0.00 \\
0.00 \\
0.00 \\
2.41 \\
0.00 \\
0.00 \\
0.00 \\
0.39 \\
0.00 \\
\text { Not done }\end{array}$ & $\begin{array}{l}0.500 \\
0.500 \\
0 \cdot 500 \\
0 \cdot 060 \\
0.500 \\
0.500 \\
0.500 \\
0.265 \\
0.500\end{array}$ & $\begin{array}{l}1.00 \\
1.00 \\
1.00 \\
3.34 \\
1.00 \\
1.00 \\
1.00 \\
1.22 \\
1.00\end{array}$ \\
\hline
\end{tabular}

* HOMOG assumes that there are two family types, one with linkage $(\theta<1 / 2)$ and one withou linkage $(\theta=1 / 2)$

No $=$ number of families tested.

$L(R)=$ likelihood ratios in favour of heterogeneity.

The results of pairwise analyses between each of the 10 DNA markers and the MFS1 locus obtained by using the CRI-MAP program are presented in table 5 . Since the algorithms incorporated in CRI-MAP do not carry out a full likelihood calculation (which may lead to the loss of some available information), ${ }^{1520}$ we also used the MLINK program to confirm and compare the estimated values of recombination fractions between $M F S 1$ and the marker loci. The summary of pairwise lod scores of MFS1 versus each marker locus, using both CRI-MAP and LINKAGE programs, is shown in table 6. Two of the markers, $D 15 S 48$ and $D 15 S 1$, are closely linked to MFS1 $(\theta=0.03)$. The upper $99 \%$ confidence limits ( -2 lods of $\mathrm{Zmax}$ ) for these two markers are $12 \%$ and $13 \%$ respectively. All the other markers showed looser linkage to the MFS1 locus in both males and females. There are only two phase known recombinants (excluding the French family) between D15S1 and $M F S 1$ in a total of 134 informative meioses scored. One of these recombinants is in a 12 year old affected female. ${ }^{8}$ The second recombinant is in an 8 year old affected male with Marfanoid habitus and dilatation of the aortic root. The original typing of these two subjects and their immediate relatives has been confirmed after the resampling and retyping of those subjects concerned. The two recombinants for $D 15 S 1$ are the only ones reported so far. In the original Finnish families ${ }^{5}$ (L Peltonen, personal communication) and the four families reported by Dietz et $a l^{6}$ there are no recombinants between $M F S 1$ and $D 15 S 1$. Out of a total of 124 informative meioses scored in 16 pedigrees, there were only two phase unknown recombinants between $M F S 1$ and D15S48. Other recombinants for D15S48 have also been reported previously. ${ }^{6}$ Application of the $\chi^{2}$ test $^{26}$ for sex specific and sex averaged lod scores obtained by the CRI-MAP program (table 6 ) showed significance for the MFS1-D15S45 interval $\left(\chi_{1}^{2}=5.57, \mathrm{p}=0.018\right)$.

There is a total of 64 recombinant events (40 maternally and 24 paternally derived) in the 21 families studied here. Examination of those crossovers showed that they involved 53 subjects. Some subjects were crossed over for more than two markers while others showed crossovers in both maternal and paternal chromosomes. Given the order of loci obtained in this study (table 8), six subjects were scored as possible double crossovers. The phase of parental chromosome in five of these subjects was unknown and, additionally, four of the crossovers occurred in the unaffected spouse's chromosome. The only phase known double crossover was scored in an affected male whose affected mother was only informative for D15S25 and D15S49. All affected members of this family have skeletal, cardiovascular, and ocular manifestations. The confirmed crossover was $D 15 S 25-X-M F S 1-X-D 15 S 49$. Since the genetic distance between D15S25 and D15S49 in the CEPH families is estimated to be around $15 \mathrm{cM}$ (table 7), the observation of this double crossover could be explained given the estimated map distances between the two loci.

The sex averaged results of the two point linkage obtained from the MLINK program

Table 5 Two point linkage between the MFS1 locus and the marker loci (results are from CRI-MAP program).

\begin{tabular}{|c|c|c|c|c|c|c|c|c|c|c|c|}
\hline Locus & & 0.001 & 0.05 & $0 \cdot 10$ & 0.15 & $0 \cdot 20$ & 0.25 & 0.30 & 0.35 & 0.40 & 0.45 \\
\hline$D 15 S 24$ & $\begin{array}{l}F \\
M \\
M+F\end{array}$ & $\begin{array}{r}-12 \cdot 04 \\
-2 \cdot 54 \\
-15 \cdot 58\end{array}$ & $\begin{array}{r}-2 \cdot 11 \\
0.60 \\
-2.51\end{array}$ & $\begin{array}{r}-0.59 \\
0.93 \\
-0.66\end{array}$ & $\begin{array}{l}0.17 \\
1.00 \\
0 \cdot 17\end{array}$ & $\begin{array}{l}0.60 \\
0.96 \\
0.56\end{array}$ & $\begin{array}{l}0 \cdot 85 \\
0 \cdot 86 \\
0 \cdot 71\end{array}$ & $\begin{array}{l}0.97 \\
0.72 \\
0.69\end{array}$ & $\begin{array}{l}1.00 \\
0.55 \\
0.55\end{array}$ & $\begin{array}{l}0.96 \\
0.38 \\
0.35\end{array}$ & $\begin{array}{l}0.90 \\
0 \cdot 24 \\
0 \cdot 14\end{array}$ \\
\hline$D 15 S 25$ & $\begin{array}{l}\mathbf{F} \\
M \\
M+F\end{array}$ & $\begin{array}{l}1.52 \\
4.58 \\
1.51\end{array}$ & $\begin{array}{l}4 \cdot 46 \\
4 \cdot 42 \\
4 \cdot 30\end{array}$ & $\begin{array}{l}4 \cdot 57 \\
4 \cdot 26 \\
4 \cdot 25\end{array}$ & $\begin{array}{l}4 \cdot 41 \\
4.09 \\
3.92\end{array}$ & $\begin{array}{l}4.12 \\
3.90 \\
3.45\end{array}$ & $\begin{array}{l}3.75 \\
3.71 \\
2.89\end{array}$ & $\begin{array}{l}3 \cdot 31 \\
3 \cdot 51 \\
2 \cdot 27\end{array}$ & $\begin{array}{l}2.83 \\
3.30 \\
1.61\end{array}$ & $\begin{array}{l}2.33 \\
3 \cdot 10 \\
0.96\end{array}$ & $\begin{array}{l}1.87 \\
2.92 \\
0.39\end{array}$ \\
\hline$D 15 S 2$ & $\begin{array}{l}\mathbf{F} \\
M \\
M+F\end{array}$ & $\begin{array}{r}0.70 \\
-4.38 \\
-5.69\end{array}$ & $\begin{array}{l}2.01 \\
0.57 \\
0.56\end{array}$ & $\begin{array}{l}1.91 \\
1.31 \\
1.20\end{array}$ & $\begin{array}{l}1.67 \\
1.66 \\
1.32\end{array}$ & $\begin{array}{l}1.40 \\
1.86 \\
1.24\end{array}$ & $\begin{array}{l}1.11 \\
1.96 \\
1.06\end{array}$ & $\begin{array}{l}0.84 \\
2.00 \\
0.83\end{array}$ & $\begin{array}{l}0.59 \\
2.01 \\
0.59\end{array}$ & $\begin{array}{l}0.39 \\
1.99 \\
0.37\end{array}$ & $\begin{array}{l}0.23 \\
1.96 \\
0.18\end{array}$ \\
\hline$D 15 S 1$ & $\begin{array}{l}\mathbf{F} \\
\mathbf{M}+\mathbf{F}\end{array}$ & $\begin{array}{l}7.20 \\
3.93 \\
3.92\end{array}$ & $\begin{array}{l}6.68 \\
6.98 \\
6.44\end{array}$ & $\begin{array}{l}6 \cdot 13 \\
7 \cdot 21 \\
6 \cdot 12\end{array}$ & $\begin{array}{l}5 \cdot 55 \\
7 \cdot 17 \\
5 \cdot 51\end{array}$ & $\begin{array}{l}4 \cdot 96 \\
7 \cdot 02 \\
4 \cdot 77\end{array}$ & $\begin{array}{l}4.34 \\
6.79 \\
3.94\end{array}$ & $\begin{array}{l}3.71 \\
6.52 \\
3.08\end{array}$ & $\begin{array}{l}3 \cdot 09 \\
6 \cdot 20 \\
2 \cdot 20\end{array}$ & $\begin{array}{l}2.49 \\
5.86 \\
1.37\end{array}$ & $\begin{array}{l}1.96 \\
5.50 \\
0.62\end{array}$ \\
\hline$D 15 S 48$ & $\begin{array}{l}\mathbf{F} \\
\mathbf{M}+\mathbf{F}\end{array}$ & $\begin{array}{r}9.63 \\
12.09 \\
9.63\end{array}$ & $\begin{array}{l}12 \cdot 10 \\
11.68 \\
11.68\end{array}$ & $\begin{array}{l}11 \cdot 70 \\
11 \cdot 24 \\
10 \cdot 85\end{array}$ & $\begin{array}{r}11.01 \\
10 \cdot 79 \\
9.72\end{array}$ & $\begin{array}{r}10 \cdot 17 \\
10 \cdot 31 \\
8 \cdot 43\end{array}$ & $\begin{array}{l}9.23 \\
9.81 \\
7.03\end{array}$ & $\begin{array}{l}8 \cdot 20 \\
9 \cdot 29 \\
5 \cdot 56\end{array}$ & $\begin{array}{l}7 \cdot 11 \\
8 \cdot 77 \\
4 \cdot 04\end{array}$ & $\begin{array}{l}5.96 \\
8 \cdot 25 \\
2.52\end{array}$ & $\begin{array}{l}4.85 \\
7.76 \\
1.12\end{array}$ \\
\hline$D 15 S 49$ & $\begin{array}{l}\mathbf{F} \\
\mathbf{M} \\
\mathbf{M}+\mathbf{F}\end{array}$ & $\begin{array}{r}-3.08 \\
2.48 \\
-2.99\end{array}$ & $\begin{array}{l}1.68 \\
2.41 \\
1.70\end{array}$ & $\begin{array}{l}2 \cdot 26 \\
2 \cdot 33 \\
2 \cdot 16\end{array}$ & $\begin{array}{l}2 \cdot 45 \\
2 \cdot 24 \\
2 \cdot 23\end{array}$ & $\begin{array}{l}2 \cdot 48 \\
2 \cdot 15 \\
2 \cdot 14\end{array}$ & $\begin{array}{l}2.40 \\
2.05 \\
1.93\end{array}$ & $\begin{array}{l}2.26 \\
1.94 \\
1.66\end{array}$ & $\begin{array}{l}2.06 \\
1.83 \\
1.32\end{array}$ & $\begin{array}{l}1.82 \\
1.70 \\
0.93\end{array}$ & $\begin{array}{l}1.53 \\
1.56 \\
0.49\end{array}$ \\
\hline$D 15 S 51$ & $\begin{array}{l}\mathbf{F} \\
\mathbf{M}+\mathbf{F}\end{array}$ & $\begin{array}{l}0.22 \\
0.10 \\
0.32\end{array}$ & $\begin{array}{l}0.23 \\
0.08 \\
0.31\end{array}$ & $\begin{array}{l}0.23 \\
0.06 \\
0.28\end{array}$ & $\begin{array}{l}0.19 \\
0.04 \\
0.23\end{array}$ & $\begin{array}{l}0.19 \\
0.02 \\
0 \cdot 21\end{array}$ & $\begin{array}{l}0 \cdot 14 \\
0.01 \\
0 \cdot 15\end{array}$ & $\begin{array}{l}0 \cdot 13 \\
0 \cdot 00 \\
0 \cdot 14\end{array}$ & $\begin{array}{l}0.09 \\
0.00 \\
0.08\end{array}$ & $\begin{array}{l}0.07 \\
0.00 \\
0.07\end{array}$ & $\begin{array}{l}0.03 \\
0.00 \\
0.02\end{array}$ \\
\hline$D 15 S 45$ & $\begin{array}{l}\mathbf{F} \\
\mathbf{M} \\
\mathbf{M}+\mathbf{F}\end{array}$ & $\begin{array}{r}-0.58 \\
5.19 \\
-0.59\end{array}$ & $\begin{array}{l}4 \cdot 26 \\
4 \cdot 75 \\
3 \cdot 81\end{array}$ & $\begin{array}{l}4 \cdot 89 \\
4 \cdot 29 \\
3.97\end{array}$ & $\begin{array}{l}5.12 \\
3.80 \\
3.72\end{array}$ & $\begin{array}{l}5 \cdot 20 \\
3 \cdot 28 \\
3 \cdot 28\end{array}$ & $\begin{array}{l}5.17 \\
2.75 \\
2.73\end{array}$ & $\begin{array}{l}5.09 \\
2 \cdot 21 \\
2 \cdot 11\end{array}$ & $\begin{array}{l}4.96 \\
1.67 \\
1.47\end{array}$ & $\begin{array}{l}4 \cdot 81 \\
1 \cdot 17 \\
0 \cdot 86\end{array}$ & $\begin{array}{l}4.66 \\
0.76 \\
0.35\end{array}$ \\
\hline$D 15 S 29$ & $\begin{array}{l}\mathbf{F} \\
\mathbf{M} \\
\mathbf{M}+\mathbf{F}\end{array}$ & $\begin{array}{r}-5.60 \\
2.02 \\
-8.21\end{array}$ & $\begin{array}{l}1.29 \\
3.34 \\
1.28\end{array}$ & $\begin{array}{l}2.38 \\
3.23 \\
2.33\end{array}$ & $\begin{array}{l}2.90 \\
2.98 \\
2.60\end{array}$ & $\begin{array}{l}3.17 \\
2.65 \\
2.53\end{array}$ & $\begin{array}{l}3 \cdot 30 \\
2 \cdot 28 \\
2 \cdot 26\end{array}$ & $\begin{array}{l}3.34 \\
1.87 \\
1.87\end{array}$ & $\begin{array}{l}3.32 \\
1.43 \\
1.39\end{array}$ & $\begin{array}{l}3 \cdot 27 \\
1.00 \\
0 \cdot 89\end{array}$ & $\begin{array}{l}3 \cdot 20 \\
0.60 \\
0 \cdot 40\end{array}$ \\
\hline$D 15 S 38$ & $\begin{array}{l}\mathbf{F} \\
\mathbf{M} \\
\mathbf{M}+\mathbf{F}\end{array}$ & $\begin{array}{r}0.00 \\
-1.20 \\
-1.20\end{array}$ & $\begin{array}{l}0.00 \\
0.35 \\
0.35\end{array}$ & $\begin{array}{l}0.00 \\
0.49 \\
0.49\end{array}$ & $\begin{array}{l}0.00 \\
0.49 \\
0.49\end{array}$ & $\begin{array}{l}0.00 \\
0.44 \\
0.44\end{array}$ & $\begin{array}{l}0.00 \\
0.36 \\
0.36\end{array}$ & $\begin{array}{l}0.00 \\
0.26 \\
0.26\end{array}$ & $\begin{array}{l}0.00 \\
0 \cdot 17 \\
0 \cdot 17\end{array}$ & $\begin{array}{l}0.00 \\
0.08 \\
0.08\end{array}$ & $\begin{array}{l}0.00 \\
0.02 \\
0.02\end{array}$ \\
\hline
\end{tabular}


Table 6 Comparison of two point lod scores from CRI-MAP and LINKAGE programs.

\begin{tabular}{|c|c|c|c|c|c|c|c|c|}
\hline \multirow[b]{3}{*}{ Loci pair } & \multicolumn{5}{|c|}{ CRI-MAP } & \multicolumn{3}{|c|}{ LINKAGE } \\
\hline & \multicolumn{3}{|c|}{ Sex specific } & \multicolumn{2}{|c|}{ Sex averaged } & \multicolumn{2}{|c|}{ Sex averaged } & \multirow{2}{*}{$\begin{array}{c}-1 \text { lods confidence } \\
\text { interval }\end{array}$} \\
\hline & $\theta_{\mathrm{m}}$ & $\theta_{\mathrm{f}}$ & Lods & $\theta$ & Lods & $\theta$ & Lods & \\
\hline $\begin{array}{l}\text { MFS1-D15S24 } \\
M F S 1-D 15 S 25 \\
M F S 1-D 15 S 2 \\
M F S 1-D 15 S 1 \\
M F S 1-D 15 S 48 \\
M F S 1-D 15 S 49 \\
M F S 1-D 15 S 51 \\
M F S 1-D 15 S 45 \\
M F S 1-D 15 S 29 \\
M F S 1-D 15 S 38\end{array}$ & $\begin{array}{l}0.15 \\
0.00 \\
0.33 \\
0.11 \\
0.00 \\
0.00 \\
0.00 \\
0.00 \\
0.05 \\
0.13\end{array}$ & $\begin{array}{l}0.34 \\
0.09 \\
0.05 \\
0.00 \\
0.04 \\
0.18 \\
0.01 \\
0.21 \\
0.31 \\
0.00\end{array}$ & $\begin{array}{c}1 \cdot 00 \\
4 \cdot 58 \\
2 \cdot 01 \\
7 \cdot 21 \\
12 \cdot 10 \\
2 \cdot 48 \\
0 \cdot 32 \\
5 \cdot 20^{*} \\
3 \cdot 34 \\
0 \cdot 50\end{array}$ & $\begin{array}{l}0.27 \\
0.07 \\
0.15 \\
0.05 \\
0.03 \\
0.14 \\
0.00 \\
0.09 \\
0.15 \\
0.13\end{array}$ & $\begin{array}{c}0.72 \\
4.34 \\
1.32 \\
6 \cdot 44 \\
11 \cdot 79 \\
2.24 \\
0.32 \\
3.99^{*} \\
2.60 \\
0.50\end{array}$ & $\begin{array}{l}0.21 \\
0.04 \\
0.08 \\
0.03 \\
0.03 \\
0.15 \\
0.00 \\
0.08 \\
0.26 \\
0.38\end{array}$ & $\begin{array}{r}1 \cdot 48 \\
7 \cdot 53 \\
4 \cdot 31 \\
12 \cdot 73 \\
17 \cdot 24 \\
2 \cdot 87 \\
0.31 \\
5.85 \\
1.29 \\
0.05\end{array}$ & $\begin{array}{l}0.09 \rightarrow 0.40 \\
0.00 \rightarrow 0.13 \\
0.02 \rightarrow 0.21 \\
0.00 \rightarrow 0.09 \\
0.00 \rightarrow 0.09 \\
0.05 \rightarrow 0.33 \\
0.00 \rightarrow 0.50 \\
0.02 \rightarrow 0.19 \\
0.13 \rightarrow 0.46 \\
0.00 \rightarrow 0.50\end{array}$ \\
\hline
\end{tabular}

* Test for $\theta_{\mathrm{m}}=\theta_{\mathrm{f}}$ is significant $\left(\chi_{1}^{2}=5 \cdot 57, \mathrm{p}=0.018\right)$.

were used to test for homogeneity of the MFS1 family panel with regard to the DNA markers studied by the members of the Consortium (table 4). In order to conduct a more accurate test, we also calculated the multipoint linkage likelihoods for each family, assuming the most likely order as obtained from the CEPH dataset (table 7) and by placing the MFS1 locus between the D15S1 and D15S48. Following the conversion of these likelihoods into their equivalent lod scores they were used in the HOMOG program to test for heterogeneity of MFS1 with respect to the marker loci. As shown in table 4, by excluding the French family the likelihood ratios in favour of heterogeneity of the MFS1 locus do not reach the 5\% level of significance for any of the markers tested or for the multipoint lod scores (with a likelihood ratio of 1.00 ). Thus, $M F S 1$ is linked to chromosome 15 markers in all of the 21 families studied here.

The estimated genetic distance between most of the markers in the present sample is larger than those estimated in the CEPH panel (data not shown). This is mainly because most typings in the Marfan families have been performed selectively, so that not all of the families are genotyped for all of the 10 DNA markers. Because of this, we have decided to construct the 10 point map of markers using both the CRI-MAP program and the CEPH family

Table 7 Ten point linkage map of loci on $15 q 15 \rightarrow q 21$ region. Map is generated using the CEPH genotypic data.

\begin{tabular}{|c|c|c|c|c|c|}
\hline & & \multirow{2}{*}{$\frac{\text { Sex averaged }}{\theta \mathrm{cM}}$} & \multicolumn{2}{|c|}{ Sex specific } & \multirow{2}{*}{$\begin{array}{l}\text { Odds against inversion } \\
\text { of adjacent loci }\end{array}$} \\
\hline & & & $\theta_{\mathrm{m}}$ & $\theta_{\mathrm{f}}$ & \\
\hline & $D 15 S 24$ & $23 \cdot 6$ & $25 \cdot 7$ & $20 \cdot 6$ & $10^{15}: 1$ \\
\hline & DI5S1 & $7 \cdot 6$ & $10 \cdot 0$ & $4 \cdot 6$ & $145: 1$ \\
\hline$D 15 S \underline{\underline{2 b}}$ & D15S48 & $1 \cdot 1$ & 0.0 & $2 \cdot 7$ & $71: 1$ \\
\hline c & $D 15549$ & $5 \cdot 3$ & 3.6 & $6 \cdot 5$ & $10^{4}: 1$ \\
\hline \multirow{2}{*}{\multicolumn{2}{|c|}{$\begin{array}{r}D 15 S 49 \\
D 15 S 51-\left[\bar{D} 15 S 45^{*}\right.\end{array}$}} & $14 \cdot 0$ & $12 \cdot 2$ & $15 \cdot 1$ & $10^{15}: 1$ \\
\hline & & $9 \cdot 2$ & $2 \cdot 2$ & $15 \cdot 6$ & $10^{5}: 1$ \\
\hline \multicolumn{2}{|c|}{$D 15 S 38-D 15 S 29 \dagger$} & $60 \cdot 7$ & 53.6 & 65.0 & \\
\hline
\end{tabular}

The likelihood comparison for sex averaged and sex specific is statistically significant $\left(\chi_{7}^{2}=20 \cdot 17\right.$, $\mathrm{p}=0.005$ ).

Odds for placement of $D 15 S 2=1: 9.57$ (least likely)

b Odds for placement of D15S2 $=1: 1$ (most likely).

c Odds for placement of D15S2 =1:1.02

* Haplotyped system (distances not forced to 0.0 ).

+ Haplotyped system (distances forced to 0.0 ). panel as described before. We first made an initial framework map ${ }^{23}$ with likelihood ratios of $\geqslant 1000: 1$ (lods of $\geqslant 3.00$ ) and subsequently inserted other loci into it. Every time a new marker was inserted into the map and a new order was obtained, all the loci were permutated to check the validity of the map. Since there are no recombinants in the interval of D15S29D15S38 in the CEPH families $(\mathrm{Z}=12.33)$ and, additionally, they are known to be from the same cosmid clone, ${ }^{17} 18$ these two markers were haplotyped while building up the map. Similarly, since there are no recombinants between D15S51 and D15S45 in the CEPH family panel $(Z=4.92)$, they were always kept together (haplotyped, but distances not forced to 0.0 ) for further analysis. This process was continued until the following most likely order was obtained: D15S24-D15S25-D15S1-D15S48D15S49-(D15S45-S51)-(D15S29/S38).

When all the loci within this map were permutated two to three loci at a time, only two orders out of a total of 21 tested had likelihood ratios of $\langle 1000: 1$. The first of these orders inverts the position of D15S25 and D15S1 (145 times less likely); the second order inverts the position of D15S1 and D15S48 (71 times less likely). The sex specific and sex averaged genetic maps for the above order are shown in table 7 . Distances in each interval were computed from the maximum likelihood estimates of recombination fractions using the Kosambi mapping function and are measured in $\mathrm{cM}$. The overall length of this map is $53.6 \mathrm{cM}$ in males and $65.0 \mathrm{cM}$ in females with an averaged map distance of $60.7 \mathrm{cM}$. Comparison of the likelihood for sex specific and sex averaged maps is statistically significant $\left(\chi_{7}^{2}=20 \cdot 17, \mathrm{p}=0.005\right)$. We have not been able to position $D 15 S 2$ in relation to the $D 15 S 1$ D15S48 interval. However, all other odds against the location of $D 15 S 2$ in any other position of this map were $>1000: 1$.

We then used this map and attempted to insert the MFS1 locus using all the 21 families (excluding the French family) that were contributed by the Consortium members. The evidence for the location of MFS1 is summarised in table 8. The most likely location for MFS1 is between D15S1 and D15S48. The second best location is between D15S25 and D15S1 (odds against it being 676:1). All other locations had odds of greater than 1000:1 against that order.

d


Table 8 Evidence supporting the location of the MFS1 locus.

\begin{tabular}{lcc}
\hline Insertion of MFS1 locus into the fixed map & $\begin{array}{c}\text { Location } \\
\text { score }\end{array}$ & $\begin{array}{c}\text { Odds against the } \\
\text { location of the } \\
\text { MFS1 locus }\end{array}$ \\
\hline MFS1-S24-S25-S1-S48-S49-S45-(S29,S38) & $5 \cdot 028$ & $10^{15}: 1$ \\
S24-MFS1-S25-S1-S48-S49-S45-(S29,S38) & 15.970 & $10^{4}: 1$ \\
S24-S25-MFS1-S1-S48-S49-S45-(S29,S38) & $17 \cdot 366$ & $676: 1$ \\
S24-S25-S1-MFS1-S48-S49-S45-(S29,S38) & $20 \cdot 191$ & Best order \\
S24-S25-S1-S48-MFS1-S49-S45-(S29,S38) & $16 \cdot 680$ & $10^{4}: 1$ \\
S24-S25-S1-S48-S49-MFS1-S45-(S29,S38) & $14 \cdot 924$ & $10^{5}: 1$ \\
S24-S25-S1-S48-S49-S45-MFS1-(S29,S38) & $11 \cdot 340$ & $10^{9}: 1$ \\
S24-S25-S1-S48-S49-S45-(S29,S38)-MFS1 & $10 \cdot 109$ & $10^{10}: 1$ \\
\hline
\end{tabular}

\section{Discussion}

Genetic linkage analysis of 2111 genotypes with 10 DNA markers in 22 families contributed by five members of the MFS1 Consortium provided the means for an accurate estimate of recombination fraction and confidence intervals. Initial analysis of recombinants identified one family as being different from the others. Since the heterogeneity testing for this family as compared with the others was significant, this family was excluded from further analysis. The two markers D15S1 and D15S48 showed close linkage to the MFS1 locus $(\theta=0.03)$. Sex averaged and sex specific lod scores computed between all the markers and the MFS1 locus confirm linkage of all DNA markers both in males and in females (tables 5 and 6). However, there is a significant excess of recombination in females for the MFS1-D15S45 ( $p=0.018)$ interval (table 6). The overall genetic map of the DNA markers in the CEPH families is estimated to be $53.6 \mathrm{cM}$ in males and $65.0 \mathrm{cM}$ in females given an excess female ratio of 1.21 (table 7 ). The overall sex difference in the estimated maps was tested by comparing the likelihood values for the sex specific and sex averaged maps. Application of $\chi^{2}$ approximation to the generalised likelihood ratio test yielded a $\chi_{7}^{2}$ of $20 \cdot 17$ which has an associated $p$ value of 0.005 .

When the two likelihood ratios of heterogeneity versus homogeneity of MFS1 were estimated (using both two point and multipoint lod scores of all the DNA markers), no significance was detected at the $5 \%$ level (table 4). This either indicates that MFS1 is a homogeneous disorder, or the present sample size is not sufficient to detect genetic heterogeneity. However, as mentioned above, one of the families showed significant heterogeneity for only D15S1 ( $\mathrm{p}=0.009)$ but not for D15S48 and other markers (table 4). This family was excluded from all subsequent analyses.

Our newly generated map for this region of chromosome 15 integrated the two previously reported maps ${ }^{1215}$ in which D15S1 was the only common marker (figure). The order of the loci in our map is in agreement with each of the two published maps with the exception of D15S49 which was previously positioned proximal to $D 15 S 48$ by Donis-Keller et $a l^{15}$ (that is 15136 times less likely in our map). The orientation of D15S24 and D15S1 in our map is also consistent with the results of cytogenetic localisation. ${ }^{113}$

The genetic linkage map of $M F S 1$ and the DNA markers can be moderately constructed with relative odds of at least $676: 1$ for the best

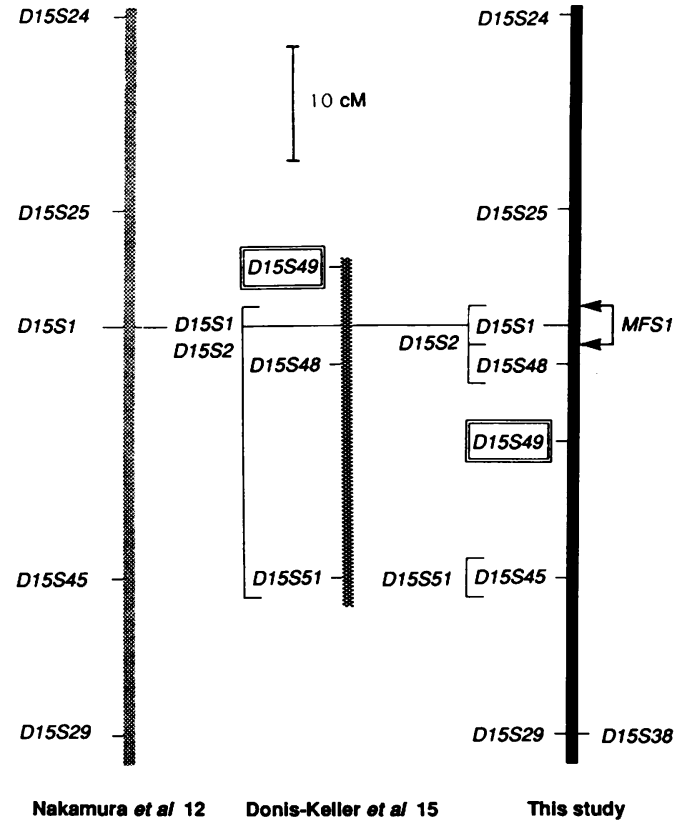

Comparison of the female map generated in this study with those published previously. Only the relevant portion of DNA markers in the two published maps that are common to this study is shown. The order of loci obtained in this study is consistent with the order of two published maps with the exception of D15S49. D15S1 was the only common marker between the two previously published maps.

order against the next alternative one (table 8). As is shown in table 8, the most likely location for the MFS1 gene is between D15S1 and D15S48. Odds against the MFS1 locus being in any other location is of a magnitude of $10^{4}$ to $10^{15}$.

The combined effort of the Consortium in pooling genotypic data brought about a common goal of defining a fine map of the MFS1 region. As a result of this effort the assignment of $M F S 1$ to the $15 \mathrm{q} 15-\mathrm{q} 21.1$ region in a total of 21 families is now established. We have also been able to identify two closely linked markers, D15S48 and D15S1. Owing to the large number of meioses studied for these markers, we can now define $99 \%$ upper confidence intervals of $12 \%$ and $13 \%$ for these two markers respectively.

Recently, the gene encoding fibrillin has been isolated and localised to chromosome $15 .^{27} 28$ Genetic linkage studies using fibrillin specific DNA markers established linkage of Marfan syndrome to this gene ${ }^{2729}$ and additionally identified mutation ${ }^{29}$ in the fibrillin gene in two isolated Marfan patients. These 
markers can now be used for diagnostic purposes in subjects at risk for this condition.

We would like to thank Dr Phil Green for the CRI-MAP program, Dr Mark Lathrop for the LINKAGE program, and Dr Jurg Ott for the HOMOG program. This work was supported in part by a grant from the Coles Family Foundation and by the National Marfan Foundation to PT, and by the British Heart Foundation and Arthritis and Rheumatic Council to AC.

1 Pyeritz RE, McKusick VA. The Marfan syndrome: diagnosis and management. $N$ Engl f Med 1979;300:772-9.

2 Beighton P, DePaepe A, Danks D, et al. Internationa nosology of heritable disorders of connective tissue, Berlin, 1986. Am ₹ Med Genet 1988;29:581-94.

3 Tsipouras P. A workshop on Marfan syndrome, 10 June 1989, Farmington, CT, USA. F Med Genet 1990;27:139 40.

4 Blanton SH, Sarfarazi M, Eiberg $\mathrm{H}$, et al. An exclusion map of Marfan syndrome. $\mathcal{F}$ Med Genet 1990;27:73-7.

5 Kainulainen K, Pulkkinen L, Savolainen A, Kaitila I, Peltonen L. Location on chromosome 15 of the gene defect causing Marfan syndrome. N Engl $f$ Med defect causing

6 Dietz HC, Pyeritz RE, Hall BD, et al. The Marfan syndrome locus: confirmation of assignment to chromosome drome locus: confirmation of assignment to chromosome $15 \mathrm{q} 15 \rightarrow \mathrm{q} 21.3$. Genomics 1991;9:355-61.

7 Tsipouras P, Sarfarazi M, Devi A, Weiffenbach B, Boxe M. Marfan syndrome is closely linked to a marker on 15q1.5 $\rightarrow$ q2.1. Proc Natl Acad Sci USA 1991;88:4486-8.

8 Sarfarazi M, Tsipouras P. Unpublished data.

9 Sarfarazi M. dblink: a new database system for linkage analysis. Am ₹ Hum Genet 1990;47:198A.

10 Wolak G, Sarfarazi M. PLOT 2000: a universal pedigree plotting program. f Med Genet 1987;24:246-7.

11 Rich DC, Witkowski CM, van Tuinen P, Ledbetter DH. A highly polymorphic probe (VNTR) maps to 15 pter-q13. Cytogenet Cell Genet 1987;46:681-2.

12 Nakamura $Y$, Lathrop $M$, O'Connell $P$, Leppert $M$, Lalouel JM, White R. A mapped set of DNA markers for human chromosome 15. Genomics 1988;3:342-6.

13 Brissenden JE, Page DC, DeMartinville B, Trowsdale J, Botstein D, Francke U. Regional assignments of three polymorphic DNA segments on human chromosome 15. Genet Epidemiol 1986;3:231-9.

14 Barker D, Schafer M, White R. Restriction sites containing CpG show a higher frequency of polymorphism in human DNA Cell 1984:36:131-8.

15 Donis-Keller H, Green P, Helms C, et al. A genetic linkage map of the human genome. Cell 1987;51:319-37.

16 Fujimoto E, Nakamura Y, O'Connell $P$, et al. Isolation and mapping of a polymorphic DNA sequence (pEFZ33) on chromosome 15 (D15S45). Nucleic Acids Res $1988 ; 16: 10946$

17 Fujimoto $E$, Nakamura $Y$, O'Connell $P$, et al. Isolation and mapping of a polymorphic DNA sequence (pEFD49.3) on chromosome 15 (D15S29). Nucleic Acids Res 1988;16:10944.

18 Fujimoto E, Nakamura Y, Ballard L, et al. Isolation and mapping of a polymorphic DNA sequence (pEFD49.2) on chromosome 15 (D15S38). Nucleic Acids Res 1988;16:10943.

19 Lathrop GM, Lalouel JM, Julier C, Ott J. Strategies for multilocus linkage analysis in humans. Proc Natl Acad Sci USA 1984;74:1245-9.

20 Lander E, Green P. Construction of multilocus genetic linkage maps in humans. Proc Natl Acad Sci USA 1987;84:2363-7.

21 Ott J. Linkage analysis and family classification under heterogeneity. Ann Hum Genet 1983;47:311-20.

22 Dausset J. Le centre d'étude du polymorphisme humain. Presse Med 1986;15:1801-2.

23 Keats BJB, Sherman SL, Morton NE, et al. Guidelines for human linkage maps: an international system for human linkage maps (ISLM, 1990). Genomics 1991;9:557-60.

24 Boileau C, Jondeau G, Bonaiti C, et al. Linkage analysis of five fibrillar collagen loci in a large French Marfan syndrome family. $\mathcal{F}$ Med Genet 1990;27:78-81.

25 Boileau C, Alexandre J-A, Hariti G, et al. Evidence for genetic heterogeneity in Marfan syndrome. Eleventh International Workshop on Human Gene Mapping (HGM11), London, 18-22 August 1991: 149.

26 Ott J. Analysis of human genetic linkage. Baltimore: The Johns Hopkins University Press, 1985.

27 Lee B, Godfrey M, Vitale E, et al. Linkage of Marfan syndrome and a phenotypically related disorder to two different fibrillin genes. Nature 1991;352:330-4.

28 Maslen CL, Corson GM, Maddox BK, Glanville RW, Sakai LY. Partial sequence of a candidate gene for the Marfan syndrome. Nature 1991;352:344-7.

29 Dietz HC, Cutting GR, Pyeritz RE, et al. Marfan syndrome caused by a recurrent de novo missense mutation in the fibrillin gene. Nature 1991;352:337-9. 